\title{
sciendo
}

\section{The impact of international economic sanctions on national economies. The Islamic Republic of Iran - a case in point}

\author{
Flavius CABA-MARIA \\ Bucharest University of Economic Studies, Bucharest, Romania \\ mariaflavius19@stud.ase.ro \\ Radu-Cristian MUȘETESCU \\ Bucharest University of Economic Studies, Bucharest, Romania \\ radu.musetescu@gmail.com
}

\begin{abstract}
This paper explores the impact of economic sanctions on national economies, with specific focus on Iran. It starts by conceptualizing sanctions in the set of economic policies and include them in the framework of economic statecraft, according to literature available. Several hypotheses that attempt to anticipate the form of sanctions are advanced, according to the intensity of geopolitical competition among the states. The analysis uses the case study of the regime of United States' sanctions against the Islamic Republic of Iran. Tehran and P5+1 powers (the permanent members of the United Nations Security Council and Germany) agreed on a deal regulating the nuclear program of Iran - Joint Comprehensive Plan of Action, meaning that Iran would reduce its nuclear activities drastically in exchange of lifting economic sanctions. In spite of the initial enthusiasm, United States announced in May 2018 the unilateral withdrawal from the deal and reinstating the sanctions regime, spiking new tensions in the relation with Iran. As a result, the paper discusses the context in which Iran tries to pursue economic goals in order to ensure resilience, while the US imposes more pressure. In addition, the study also approaches the dilemma whether sanctions can ultimately generate political answers and at what costs. In this context, it is identifying several alternatives in the Iranian case, together with noting the limits of conceptual refinements in terms of sanctions' theory.
\end{abstract}

Keywords: Iran, economic sanctions, nuclear agreement, global, impact.

\section{Introduction}

Economic sanctions are a widely used tool and they have always been so in the hands of foreign policy. Even though they have a long history, the modern times mark an increase in their use. As such, the international bodies and great powers are enacting sanctions at a more rapid pace. Initially they meant to severe ties between nations, and also today they are often accompanied by tensioned relations between the sender and target country, while generally falling into the general economic statecraft category. There have been numerous questions about their effectiveness. A general answer is not strictly applicable, as they display a broad range of typology and goals. In short, the term encompasses a series of measures of commercial and financial nature to be imposed, with different variations in function and time. International relations theory embraced the sanctions originally, but the debate on their success is open in the $21^{\text {st }}$ century, as they become a visible feature of foreign policy, not only a framework for financial and trade restrictions. The case in point - Iran - represents a perfect depicter of sanctions use (over 40 year's course of actions), although the effectiveness is disputable. One dilemma of the case in point is their prolonged use and secondly, what is the measure of their success. If they are successful to begin with, why to keep it in place for such a long time.

This paper reviews how sanctions fit at an analytical level and the challenges encountered while trying to render sanctions effective, using Iran as a case study. Although Iran can provide us with an extended timeframe for the use of sanctions, for the purpose of the study we keep the focus on the debates surrounding the sanctions on the controversial nuclear 
programme and their evolution after the United States of America (US) withdrew from the Joint Comprehensive Plan of Action (JCPOA) in 2018.

In general, the sanctions embody a coercive aspect between a sender and a target. As a result, the effectiveness of economic sanctions is connected to the sender's power in relation the target's values/resources. The seriousness of sanctions is usually confirmed when they are associated with diplomatic pressure/positioning in the foreign affairs (Iftekhar, 2016). PICBE $\mid 1015$ Studying the case of Iran, a recipient of international sanctions since the very first day of establishment the Islamic Republic in 1979, we assess the different types of economic sanctions, cycles, without being able to answer regarding the concrete effectiveness of the sanctions for both economy and politics. However, they could operate rather as a complementary aspect to a set of an overall political decision, while the target is suffering the effects, mostly visible in the economy, as it is the case of Iran. Nonetheless, the Iranian regime stood the sanctions without collapsing economically and trying to identify measures to increase economic resilience and adaptations.

The paper reviews the different types of economic sanctions; includes a literature review, and an applied discussion for the case of Iran, with a focus on several factors that could prove important for sanctions' theory. As a conclusion, it draws remarks upon the interpretation of the current situation between Iran and USA.

\section{Literature review}

As mentioned previously, economic sanctions do not represent a new concept. According to Hufbauer, Schott \& Elliot (Hufbauer et al., 1990), 13 crucial cases of economic sanctions were identified to have taken place ahead of the World War I. In addition, one could go as far as Ancient Athens and observe a clear form of economic sanctions - when Pericles issued the Megaran decree as a form of protectionism against goods from Megara (Thucydides, 1997).

Sanctions literature has met several phases. Initially (before 1989), the concept of economic sanctions was met with optimism thinking it was pursuing its goals, the target surrendering to objectives in economic policy or at least to shifts in its international relations' behavior. At the beginning the failures have not been in the spotlight. One explication for a relative success compared to present times is that bilateral ties were stronger (sanctions affecting directly the target) and the globalization still has not been into effect. In brief, the early scholars identified up to five types of coercive measures: punishment; compliance; destabilization; signaling, and symbolism - merely demonstrative acts (Nincic \& Wellensteen, 1983).

Later on, post-1990, the literature started questioning the efficiency of sanctions. Scholars become more interested in the cost of opportunity of the sanctions. This is when the 1990 study of Hufbauer et al. cements some models that evaluate the costs implied by the coercive measures, on behalf of both sender and receiver. The findings are not satisfactory, Pape (1997) indicated a low rate of success - a mere five cases deemed successful, related to minor outcomes (see Table 1).

Table 1. Five examples of successful economic sanctions before 1989

\begin{tabular}{|l|l|l|l|l|}
\hline No. & Year of the Incident & Parties involved & Result \\
\hline $\mathbf{1}$ & 1933 & UK & USSR & USSR released six prisoners \\
\hline $\mathbf{2}$ & 1975 & US/Canada & South Korea & South Korea cancelled a reprocessing plant \\
\hline $\mathbf{3}$ & 1979 & Arab League & Canada & Canada did not move embassy \\
\hline $\mathbf{4}$ & 1987 & US & El Salvador & El Salvador did not release three prisoners \\
\hline $\mathbf{5}$ & 1989 & Nepal & Nepal agreed not to buy weapons from China \\
\hline \multicolumn{4}{|c}{ Source: authors' adaptation after Pape's study (1997) }
\end{tabular}


One decade later, Drezner (2000) launched a study that focuses on multilateral and specifically, the role of the United Nations (UN) in the sanctioning effort, being a fora that brought sanctions to the forefront.

The contemporary phase is that of refining the sanctions, framing them as "smart sanctions"/"targeted sanctions". This development happened in relation to the cases of Iran, North Korea, and Cuba, as there was increasing debate about the detrimental effects of this PICBE $\mid 1016$ foreign policy mechanism. It happened mostly in relation with deprival of the target population that went in some cases to the extent of lacking basic needs (medication, oil for transportation, etc.).

The schools of thought from Copenhagen, Berlin, and Vienna have mentioned the use of smart sanctions, when analyzing the compliance of the target to the sanctions. They debated the idea certainty of goals and outcomes when seeking to impose the economic sanctions. Moreover, if the sender power is calculating civilian costs and financial cost, the commitment to prolonged engagement is diminished especially if it translated to a negative perception in the foreign policy arena. While some scholars plead for being harsh when it comes to measures and objectives (Pape, 1998; Rodman, 2001) in order to reach the necessary outcomes, others accepting a partial success (Hufbauer et al., 1990).

Thus, one could observe a change of paradigm - sanctions turning from being imposed by states against states (comprehensive regime) to sanctions imposed on specific entities and individuals (targeted regime). Therefore, all the main sanctions enactors - the UN, European Union (EU), US have adapted to this new paradigm. This change was made on the background of the complaints about sanctions in the 1990s - namely the questioning of the punishment of civilians. Targeted sanctions should be avoiding negative consequences for the ordinary citizens (Amuzegar, 2010), at least in theory.

Moreover, we are the witnesses of the global era, where the effectiveness of sanctions is reduced by the reduction of trade barriers themselves. Thus, it is more difficult to sanction products in one country without encountering reverse measures for the sender country (Smeets, 2018). Along the same lines, Smeets (2018, p.5) confirms that the new realities mirror the contemporary economic processes "the emergence of global production networks and a splitting up of the production process". It is valid in particular when it comes to trade among the developed economies - the Organization for Economic Co-operation and Development (OECD) level - as it demands complex inter-connected economic processes.

When one wants to define the typology, the economic sanctions are varied, though considered equal with "economic coercion," they are portraying a slighter more restraint category than economic warfare, economic inducement, and trade war, according to purpose and opportunities. In essence, economic sanctions, according to Baldwin (1985), represent only a facet of the typology, which interferes with products with an economic value. Economic warfare weakens the overall aggregate economic potential ultimately impacting the military power. Economic warfare is a long-term plan, while economic sanctions usually seek an immediate impact. Economic inducements involve trade concessions, technology transfers and knowhow, when the sender purpose influencing a behavior on behalf of the target. For Baldwin, trade wars dispute economic models/policies (Baldwin, 1985), similar to what we witness nowadays regarding US versus China economic approaches.

This study operates with the understanding of economic sanctions, which are framed under a broad category of "economic statecraft". As such, the economic sanctions are meant to force a target to comply with the sender's preference, on precise aims. Economic sanctions "are intended primarily to coerce a change in the behavior of the targeted party" (Biersteker \& van Bergeijk, 2015, p.18). 
According to the objectives pursued, there are three main distinctions for economic sanctions, Barber (1979) classifying them in: primary, secondary, and tertiary. The primary objectives focus on the behavior of the government of a target, while the secondary objectives are related to the perceptions and expectations of the sender government. The tertiary objectives are assessed in the broader international context. All of the three categories are not excluding one another.

PICBE $\mid 1017$

When it comes to evaluation of objects of sanctions, one can range the sanctions from boycotts and embargoes to financial sanctions. The boycott signifies a constraint imposed on importing goods from a target country, while embargoes go against exports of the target country (partially or fully). The financial sanctions imply restrictions on investing in a target country, on international payments and/or freeze of assets (Caruso, 2003).

When it comes to efficiency, according to Peterson Institute for International Economics sanctions database (a vast collection of 200 cases) indicated a nonperformance in about two out of three cases (Biersteker \& van Bergeijk, 2015), whereas the Targeted Sanctions Consortium (TSC) on UN imposed sanctions suggests an even lower rate of success. It was admitted that it has rather high chances to fail as any other policy tool. The same authors argue (Biersteker \& van Bergeijk, 2015) that there are seven elements when we measure success of the implementation of economic sanctions: trade volumes prior to implementation need to be significant; the early onset of implementation count most; the psychological aspects; the more democratic the target is, the more likely are the chances for the sanctions to succeed; powerful multilateral engagement; strictly defined goals and multifactorial policies; targeted sanctions have equal chances to succeed as comprehensive ones. These factors are developed one by one and will indicate how likely that is the regime sanctions is a successful one.

Mentioning the increasing appetence for free trade, the World Trade Organization (WTO), the main preserver of free trade operates with the notion of sanctions as an outcome of the retaliatory actions resulting from dispute mechanisms allowed by the WTO legislation. The claims made under such mechanisms seek restoring rights and obligations disrupted by the breeches of the WTO rules. Smeets highlights that: "The economic and trade sanctions are mostly justified under the security exceptions and more specifically Article XXI and Article XIV bis of the General Agreement on Trade in Services (GATS) when services trade is involved" (Smeets, 2018, p.3). The WTO members can interpret the legality of sanctions through dispute settlements established under the Article XXI of the General Agreement on Tariffs and Trade (GATT) 1994 (Smeets, 2000).

Briefly, the economic sanctions touch upon several economic notions and trade has implications at diplomatic level and even generates disputes (WTO cases, International Court of Justice), despite the initial optimism for this tool effectiveness in the late 1980s, until early 1990s. However, the domain remains under-explored, especially when it comes to regimes that are not close to the West - e.g., Iran, Russia, North Korea, Venezuela, etc. Thus, the paper intends to shed light on some aspects related to the conceptualization of the notion "economic sanctions" in the case of Iran (in the more recent years, for the purpose of this study) and comprises evaluations pertaining to the situation on the ground, including current developments.

\section{Methodology}

The paper relies upon a descriptive approach regarding the notion of economic sanctions (approached in the literature review), combined with a qualitative approach (operationalizing the different facets of economic sanctions in the case of Iran) and a quantitate one when it comes to data-bases review, applying them in the case of Iran. This study equally investigates 
how economists describe various aspects of the sanctions (in the literature review part). As sanctions incorporate economic values in relation with the restrictions, policy makers need input from the economic theory (Simons, 1999).

The study takes into regard different approaches from the economic sanctions' literature. For some authors, tension can be noticed between sanctions and the paramount aspiration of the WTO: namely restricted trade vs liberalized trade.

PICBE | 1018

A main question persists and surrounds economic sanctions - are they effective? Hufbauer, Schott \& Elliott are among the first authors that question the effectiveness of economic sanctions. Yet they remain a widely used tool. All these aspects deserve additional consideration especially when it comes to empirical case constructed - namely Iran, one of the country most affected by economic sanctions, especially via US. The country that has imposed most of sanctions in the aftermath of the Second World War is the US (Caruso, 2003). Concomitantly, similar measures, imposed by multilateral organizations like the UN or the EU have occurred repeatedly in recent years. Iran suffers under the maximum height of sanctions currently, as the US administration promised (and delivered gradually) to impose the harshest sanctions regime, after it unilaterally withdrew from the JCPOA agreement.

In the case of Iran, one could observe a "promoter" country (Caruso, 2003) - i.e., the US in this case- for sanctions and its followers (lobby at the UN and EU and other regional bodies but also in bilateral plan).

For the US, the sanctions were a state policy tool mostly in the 1990s (applying it in a comprehensive manner to Iraq and former Yugoslavia, to name a few) - sanctions as economic statecraft. With the evolution of the concept, one can notice the tuning of the concept of sanctions (towards smart sanctions), because the sanctions were meant to affect leadership/certain policies of Iran rather than its citizens. Meanwhile, the basic necessities and the fulfilment of human rights for the Iran citizens are remaining problematic aspects not solved.

The US has over 40 years of cementing the enmity with Iran - and through economic sanctions it pursued to distort the target's activities or at least forced Iran to choose a more costly strategy for procurement of various technologies, which eventually turned into resilience and adaptation in terms of overall economy. The US constantly singled out Iran from the international relations, with only one exception - during president Obama's mandate, coinciding with the moment of the JCPOA agreement being struck on 14 July 2015 (adopted in October, entered into force on 16 January 2016). In exchange of economic concessions Iran agreed to slow down uranium enrichment for its nuclear programme. This diplomatic success was possible during a timeslot when US's harsh stance towards Iran attenuated. This moment was seized by the European diplomatic apparatus, which is following a more flexible line for the sake of pacifying the relations with Iran (and the region where Iran is situation, implicitly). For these considerations, Iran was made the center of this analysis, being a state that was touched by sanctions from all points of view over a prolonged timeframe. The US is utilizing its upper hand in world affairs, pressuring Iran at all levels - see the graphic (Figure 1) for the most recent actions related to the oil price - in the context of US-Iran recent pinnacle of tensions. 


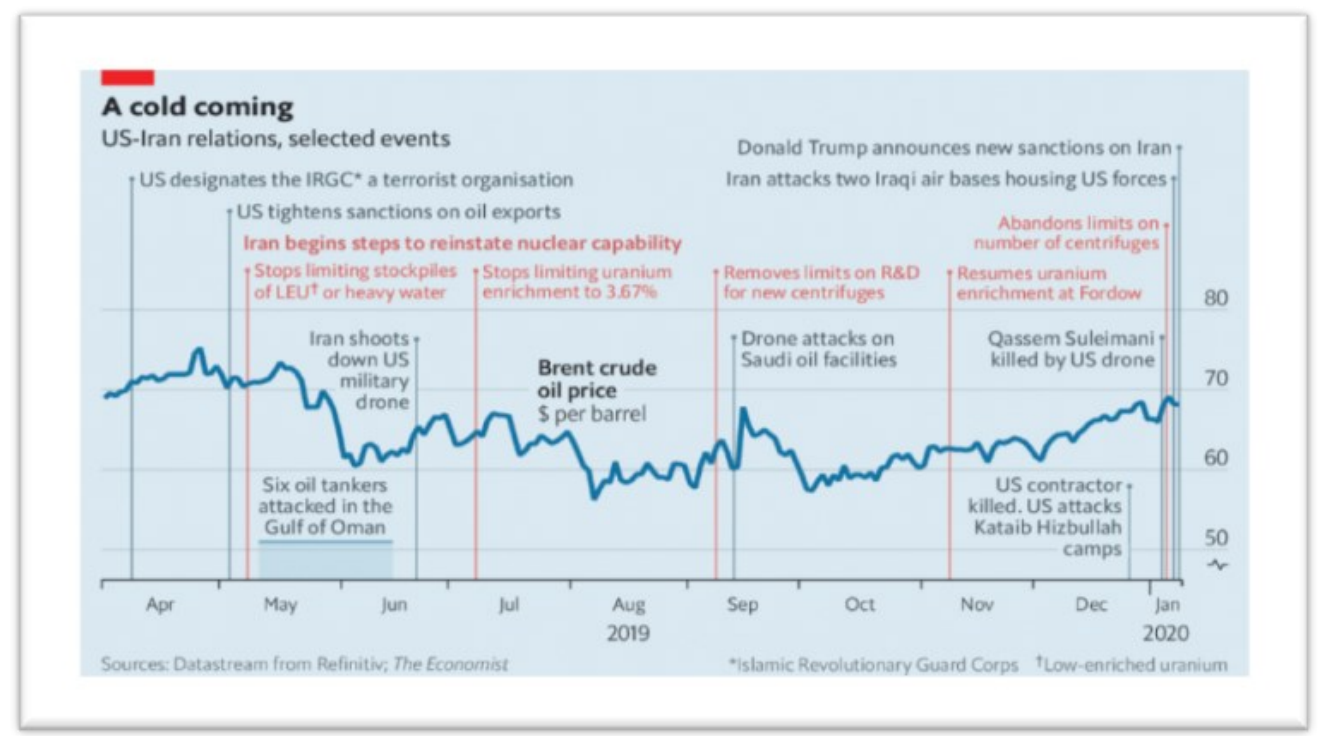

PICBE $\mid 1019$

Figure 1. Recent tensioned events in the US-Iran relations

Source: The Economist (2020), https:/www.economist.com/briefing/2020/01/09/how-iran-canrespond-to-the-killing-of-qassem-suleimani

One dilemma persists - despite the long history of sanctions, is Iran conceding? Is the US achieving its goals in relation with its targets? If not, what are the alternatives in case of non-performance? In the results and conclusion section, the study opens the debate on effectiveness and alternatives.

\section{Results and discussions}

While there is yet to draw conclusions on the multilateral activity on sanctions, there were steps in this direction. For instance, the TSC databases have received a thorough review (Biersteker et al., 2016). It resulted that the UN sanctions have detached step by step from isolation, being customized gradually to specificity. The UN sanctions frequently come in company with diplomatic efforts (97\%), sometimes with peacekeeping (62\%) and with the menace of the use of force (62\%) [Eckert, 2017]. Nowadays, regional and unilateral sanctions are usual precursors of the UN action (70\%). According to the 2016 review of UN sanctions, the sanctions are more effective when combined. It is thought that a successful combination of factors for effective sanctions comprises in almost half of the cases weapon bans, travel limitations and assets freeze (Biersteker et al., 2016). Iran has clearly received a combined strategy for sanctions.

As mentioned previously, a sender has to evaluate the target's hierarchy of values to know what can affect the target most. In the case of Iran, a long-time vulnerability was represented by the oil revenues dependency. As a result, the EU and US financial sanctions aimed to strike the core the oil industry - a calculus based upon economic and trade patterns of Iran. One of the most meaningful measures was EU's decision to exclude Iran from the Society for Worldwide Interbank Financial Telecommunications (SWIFT) global system that allows international currency flows. This decision put a lot of strain on international payments and bilateral trade (van Bergeijk \& Biersteker, 2015).

Dizaji's \& van Bergeijk's study (2013) reached a conclusion about the chronology of sanctions: their effects are most visible in the first two years subsequent to their implementation. The effect is most powerful in the first two years, fading after six-seven years, because economic adaptation comes into place. As it is the case for Iran, it did not seem to affect the leadership and the political/security apparatus. However, if we take into account 
aggregate data, such as Gross Domestic Product level, currency value, limitation of the oil revenues and receipt of international payments (with a concrete effect upon economic flows), there are visible effects of the sanctions. Currently Iran's economy is strangled by America's "maximum pressure" sanctions and undermined. Nonetheless instead of changing the course of political action, one could call it a reverse effect - we notice leaders using the sanctions background when explaining the economic stagnation and a problematic cycle of growth PICBE $\mid \mathbf{1 0 2 0}$ (Smeets, 2018).

In fact, in the wake of the US withdrawal from JCPOA, the alternatives of Iran were left to the European partners. Thus, France, UK and Germany empowered the Instrument in Support of Trade Exchanges (INSTEX) in January 2019 as a special mechanism that could facilitate European business with Iran, avoiding the transaction is US dollars, attempting to bypass the American sanctioning for those who make business with Iran. The mechanism operates with trade of humanitarian goods mostly: pharmaceutical, medical, and food products. In exchange, Iran can bring the following goods to Europe: carpets, pistachios, and other specific agricultural products. Towards the end 2019, another group of European countries - Belgium, Denmark, Netherlands, Norway, and Sweden - joined the INSTEX (www.euractiv.com, 2020). At its own end, Iran's approach is of "graduated pressure" since mid-2019, invoking menaces to Europe about the potential breech of the deal, if Europeans do not fight more about maintaining it (www.bourseandbazaar.com, 2019).

As a matter of fact, Iran hoped for more far-reaching effects when trading with European participants. One should consider that the European found themselves between a rock and a hard place. On one hand, there is the attractiveness of keeping valid a hard-worked deal, with mutual economic benefits, and on the other hand, there is the US decision to withdraw from the deal. A decision against US's policy towards Iran would breach the transAtlantic community' unity. Iran's patience was gradually fading regarding the deal especially that before mid-2019, it was complying with all the JCPOA' requirements, proven by verification of the International Atomic Energy Agency (IAEA), the UN and European governments (IAEA, July 2019). The tensions generated by the situation, made Iran turn to another channel, namely the Swiss counterparts, for humanitarian purposes. Currently, they have elaborated a channel (enabled in the aftermath of prolonged diplomatic talks) in order to ensure the flows of food and drugs to Iran, namely the Swiss Humanitarian Trade Arrangement (SHTA) (www.almonitor, 2020). It started to operate as a trial in February 2020, taking advantage that what we deem as humanitarian supplies (food, medication, and the alike) are exempted from the maximum pressure regime of sanctions imposed by the US.

In theory, one can assume that the target country has little space of maneuver in the times of sanctions, as it supposed it needs the good it is banned from (Smeets, 2018), although Iran indicated an overall resilience. In the globalized channel of production and markets it is more difficult to disrupt and single out one country. Thus, the alternatives for Iran moved their center of gravity towards collaborators in Europe and Asia. The year 2019 limited Iran leaders materially, but it has not brought the regime down that worked constantly to keep its functionality with any means (it has even stretched their visions). With some reforms in the macroeconomic policies (some have occurred already over the past years), the government would maintain its capacity in managing economic affairs, deviating the pursued goals of sanctions. Iran's story is still unfolding after facing longstanding sanctions, and noting the elements highlighted by the study of Dizaji \& van Bergeijk (2013), economic adaptations occurred, they could attenuate negative effects accordingly after another six years from now. 


\section{Conclusion}

Iran was selected as the case in point for study, as it is probably representing the country under the harshest sanctions regime (the maximum pressure policy of recent date enacted by the Trump Administration), with a history repeated sanctions spanning over four decades.

There are both unilateral (US imposed), but also international (UN, EU, other bodies)

imposed sanctions that challenged the Iranian economy over the past few decades, among PICBE $\mid \mathbf{1 0 2 1}$ which the recent ones related to the nuclear programme have had strong impact (Bazaboondi, 2015). They strike a wide variety of sectors, ranging from the military and strategic sectors, to banking, insurance, and financial service. They translate into a more significant drop of international economic flows, devaluation of the currency, drop in exports (Arnold, 2015).

Iran was placed under a comprehensive set of sanctions, but it ultimately struck a deal with the world powers in 2015 over the contested nuclear programme. Removal of sanctions after the July 2015 deal would have helped the economy, while the reinstatement post-2018 imposes further pressure on civilian population that faces restricted access to different daily life products.

The use of targeted/smart sanctions has become a focus of attention of the latest scholarship and practice with regards to economic sanctions, being supposedly a customized policy tool, which spares the population from deprival (at least in theory). Nonetheless, the fact that Iran had to customize humanitarian channels via Swiss diplomacy is an indicator that the basic necessities were increasingly difficult to fulfill, despite the idea behind targeted sanctions.

We recommend for a further detailed study to develop the evaluation of the seven factors for success of the economic sanction as an empirical study for the case of Iran, conceptualizing whether the economic sanctions are a policy tool with proven utility. The literature has yet to answer a lot of questions in this sense, especially when it comes to alternatives when sanctions fail to deliver and providing with solutions - an additional concern of the future study. One has to take into account that sanctions prompt as well vital answers from decision-makers, which in time relocate their costs and moderate their final impact (Jones, 2015).

It is true that at the moment the US policy of pressure inhibits Iran's economy, which displays obvious material limitations (www.economist.com, 2020). In addition, US decisions also inhibit more pro-active measures from behalf of the European powers, preventing the previous efforts to reach their potential. However, Dizaji's \& van Bergeijk's study (2013) concluded that economic sanctions have a time span of two years efficiency, following the implementation of sanctions. In the case of Iran, the economy has followed a lot of permutation throughout the decades and managed to identify the alternative survival mechanisms. The INSTEX and the Swiss humanitarian channel are among the proposed alternatives, but we do not know yet their extent of viability in economic terms, as they deal only with daily needs products and they have only worked limitedly. Moreover, the dilemma remains - how and what defines the factor of success for sanctions? In the case in point, the Iranian leadership remains solid, despite the adversities, without fundamental changes in direction. Concomitantly, after some many trials to refine the concept of sanctions, reaching the level known as smart sanctions one could still notice they are rather in a complementarity relation to other means, with a limited rate of performance.

\section{References}

Amuzegar, J. (2010). Iran's fourth plan: A partial assessment. Middle East Policy, 17(4), 114130. 
Arnold, A. (March, 2015). Current state of global sanctions against Iran. Belfer Center for Science and International Affairs. Retrieved from https://www.belfercenter.org/publication/current-state-global-sanctions-against-iran.

Baldwin, D. A. (1985). Economic statecraft. New Jersey: Princeton University Press.

Barber, J. (1979). Economic sanctions as a policy instrument. International Affairs, 55(3), 367-384.

PICBE | 1022

Bazoobandi, S. (2015). Sanctions against Iran: Winners and Losers. In Dreyer, I., LuengoCabrera, J. On target? EU sanctions as security policy tools - Issue report 25 (pp. 5765). EU Institute for Security Studies, Normandy: Conde-sur-Noireau.

Biersteker, T.J., Tourinho, M., \& Eckert, S.E. (2016). The effectiveness of United Nations targeted sanctions. Targeted Sanctions, 220-247.

Caruso, R. (2003). The impact of international economic sanctions on trade - An empirical analysis. Peace Economics, Peace Science and Public Policy. 9(2), 1-36.

Dizaji, S.F., \& van Bergeijk, P.A. (2013). Potential early phase success and ultimate failure of economic sanctions. Journal of Peace Research, 50(6), 721-736.

Drezner, D.W. (2000). Bargaining, enforcement, and multilateral sanctions: When is cooperation counterproductive?. International Organization, 54(1), 73-102.

Eckert, S.E. (2017). The evolution and effectiveness of UN targeted sanctions. Research Handbook on UN Sanctions and International Law, 52-70.

Hufbauer, G.C., Schott, J.J. \& Elliott, K.A., (1990). Economic sanctions reconsidered: History and current policy. Washington: Peterson Institute.

Iftekhar, I. (2016), Managing companies under the economic sanctions, A Case study of Iranian practice. Retrieved from https://www.slideshare.net/irfaniftekhar/a-case-studyof-irainian-practice.

Jones, L. (2015). How Do International Economic Sanctions (Not) Work?. Retrieved from https://www.files.ethz.ch/isn/194802/1708.pdf.

Nincic, M., \& Wallensteen, P. (1983). Dilemmas of economic coercion: Sanctions in world politics. Westport: Praeger Publishers.

Pape, R.A. (1997). Why economic sanctions do not work. International Security, 22(2), 90136.

Pape, R.A. (1998). Why economic sanctions still do not work. International Security, 23(1), 66-77.

Rodman, K.A. (2001). Sanctions beyond borders: Multinational corporations and U.S. economic statecraft. Maryland: Rowman \& Littlefield.

Simons, G.L. (1999). Imposing economic sanctions: Legal remedy or genocidal tool?. London: Pluto Press.

Smeets, M. (2000). Conflicting Goals: Economic Sanctions and the WTO. Global Policy Dialogue, 2(3).

Smeets, M. (2018). Can economic sanctions be effective? WTO Working Papers. No. ERSD2018-03, World Trade Organization (WTO), Geneva. Retrieved from https://www.wto.org/english/res_e/reser_e/ersd201803_e.pdf.

Thucydides (1997 ed.). Translated by Rex Warner. History of the Peloponnesian War. New York: Penguin.

Van Bergeijk, P.A.G. \& Biersteker, T. (2015). How and when do sanctions work? The evidence. In Dreyer, I., Luengo-Cabrera, J. On target? EU sanctions as security policy tools - Issue report 25 (pp. 17-28). EU Institute for Security Studies, Normandy: Conde-sur-Noireau. 
Iran's Zarif says Swiss humanitarian channel "small step". (2020, February 3). Retrieved from https://www.al-monitor.com/pulse/originals/2020/02/iran-zarif-swiss-humanitarianchannel-medicine.html.

INSTEX fails to support EU-Iran trade as nuclear accord falters. (2020, January 14).

Retrieved from https://www.euractiv.com/section/global-europe/news/instex-fails-tosupport-eu-iran-trade-as-nuclear-accord-falters/.

PICBE | 1023

Special report: A provisional assessment of INSTEX — Bourse \& bazaar. (2019, June). Retrieved from https://www.bourseandbazaar.com/research-1/2018/11/29/specialreport-on-a-humanitarian-special-purpose-vehicle-9yrnl.

IAEA: Verification and monitoring in the Islamic Republic of Iran in light of United Nations Security Council resolution 2231 (2015), [2019, July]. Retrieved from https://www.iaea.org/sites/default/files/19/07/govinf2019-9.pdf.

How Iran can respond to the killing of Qassem Suleimani. (2020, January 9). Retrieved from https://www.economist.com/briefing/2020/01/09/how-iran-can-respond-to-the-killingof-qassem-suleimani. 